\title{
PENERAPAN MODEL PEMBELAJARAN INKUIRI BERBASIS KONSEP JUAL BELI TERHADAP RESPON SISWA PADA MATA PELAJARAN STATISTIKA
}

\author{
Fitriani \\ Program Studi Pendidikan Matematika Fakultas Keguruan dan Ilmu Pendidikan \\ Universitas Muhammadiyah Tapanuli Selatan, Jl. Sutan Moh. Arief no. 32 Padangsidimpuan \\ fi3ani.hrp@gmail.com
}

\begin{abstract}
Learning is the process of interaction between students and their environment so that there is a change in behavior towards a better direction. So that in generating a positive response it is necessary to improve the learning model. This research was conducted at the fifth grade IT FAZA AZKIA Elementary School, Kelurahan Hutaraja, Kabupaten Tapanuli Selatan, Provinsi Sumatera Utara. Research uses classroom action research. The study aims to determine how students respond to the use of inquiry-based learning models based on the concept of buying and selling on statistical material. This research resulted in the response of students in the first cycle still not achieving a minimum score of $80 \%$. While the response of students in cycle second the entire response of students has reached a minimum value of $80 \%$. So that the response of students has been positive and this has increased from cycle I to cycle II.
\end{abstract}

Keywords: Student Response, Inquiry Learning Model, Buying and Selling Concept

\begin{abstract}
Abstrak. Pembelajaran adalah proses interaksi antara peserta didik dengan lingkungannya sehingga terjadi perubahan perilaku ke arah yang lebih baik. Sehingga dalam menghasilkan respon yang positif maka perlu perbaikan model pembelajaran. Penelitian ini dilaksanakan di SD IT FAZA AZKIA kelas V Kelurahan Hutaraja Kabupaten Tapanuli Selatan Provinsi Sumatera Utara. Penelitian menggunakan penelitian tindakan kelas. Penelitian bertujuan untuk mengetahui bagaimana respon siswa terhadap penggunaan model pembelajaran inkuiri berbasis konsep jual beli pada materi statistika. Penelitian ini menghasilkan respon siswa siklus I masih belum mencapai nilai minimal $80 \%$. Sedangkan respon siswa siklus II seluruh respon siswa sudah mencapai nilai minimal $80 \%$. Sehingga respon siswa sudah positif dan ini terjadi peningkatan dari siklus I sampai siklus II.
\end{abstract}

Kata Kunci: Respon Siswa, Model Pembelajaran Inkuiri, Konsep Jual Beli

\section{PENDAHULUAN}

Salah satu tujuan untuk mengembangkan potensi yang ada pada diri peserta didik agar menjadi manusia yang berakhlak dan berilmu ialah melalui proses pembelajaran yang bermakna. Bermaknanya suatu pembelajaran tidak luput dari peran seorang guru dalam mendesain dan menerapkan model-model pembelajaran yang sudah ada. Dalam hal ini guru dituntut menjadi guru profesional, menurut Kunandar (2009) guru profesional ialah guru yang mengenal dirinya, yaitu dirinya adalah pribadi yang dipanggil untuk mendampingi peserta didik untuk/dalam belajar. Sehingga diharapkan guru mampu menciptakan respon yang positif dalam diri peserta didik. Salah satu model pembelajaran yang bermakna dan mampu meningkatkan respon positif bagi siswa ialah model pembelajaran inkuiri, karena dengan model ini peserta didik lebih leluasa dalam bereksprimen dan mengeluarkan pendapat. Menurut Kunandar (2009) pembelajaran inkuiri ialah pendekatan pembelajaran dimana siswa didorong untuk belajar melalui keterlibatan aktif mereka sendiri dengan konsep-konsep dan prinsip-prinsip dan guru mendorong siswa untuk mengalami pengalaman dan melakukan percobaan yang memungkinkan siswa menemukan prinsipprinsip untuk diri mereka sendiri. Dalam penerapan model inkuiri ini melibatkan model belajar secara koperatif, karena model koperatif diyakini sebagai praktik pedagogis untuk meningkatkan proses pembelajaran, gaya berpikir tingkat tinggi, perilaku sosial, sekaligus 
kepedulian terhadap siswa-siswa yang memiliki latar belakang kemampuan, penyesuaian, dan kebutuhan yang berbeda-beda. Hal ini sesuai pendapat Djamarah (2006) menyatakan bahwa tidak ada makhluk hidup yang terus menerus berdiri sendiri tanpa keterlibatan makhluk lain, langsung atau tidak langsung, disadari atau tidak, makhluk lain itu ikut ambil bagian dalam kehidupan makhluk tertentu. Artinya kooperatif sangat perlu diterapkan baik di dalam dunia pendidikan ataupun dalam bermasyarakat.

Namun kenyataannya berdasarkan hasil pengamaan pada saat guru matematika melakukan proses pembelajaran di SD IT Faza Azkia ialah menggunakan proses pembelajaran biasa. Dan juga respon peserta didik tidak terlalu aktif dan positif dimana masih ditemukan siswa yang ribut, tidak memperhatikan guru dan asik mengganggu teman lain dalam mengikuti proses pembelajaran. Berdasarkan permasalahan yang terjadi maka sepantasnya perlu dilakukan perbaikan sehingga secara tidak langsung akan berakibat pada respon siswa. Dalam hal ini dikhususkan pada respon matematik siswa.

Respon siswa merupakan salah satu ungkapan hati ataupun perasaan seseorang terhadap sesuatu yang baru dilalui, yang baru dirasakan dan yang baru dilihat. Respon yang harus dikuasai oleh peserta didik ialah respon positif ataupun pandangan positif yang dapat membangun emosi peserta didik, karena jika peserta didik tidak memiliki respon positif terhadap matematika khususnya maka peserta didik akan kesulitan dalam mengikuti materi-materi selanjutnya. Hal ini sejalan dengan pendapat Usman (Rohman, 2013) bahwa keterlibatan siswa dalam belajar erat kaitannya dengan sifat-sifat siswa, baik yang bersifat kognitif seperti kecerdasan dan bakat maupun yang bersifat afektif, seperti motivasi, rasa percaya diri, dan minatnya. Artinya dalam mempelajari matematika peserta didik harus memiliki respon yang bersifat positif terlebih dahulu agar dapat menyelesaikan soal-soal dan mampu mengaplikasikan pembelajaran tersebut di dunia nyata.

Berdasarkan pentingnya respon dimiliki peserta didik maka seorang guru harus mampu menyesuaikan model-model pembelajaran yang bermakna bagi para peserta didik agar pembelajaran yang berlangsung tidak sia-sia. Hal ini sejalan dengan pendapat Slameto (Herawati, 2010) pembelajaran matematika sangat ditentukan oleh strategi dan pendekatan yang digunakan dalam mengajar matematika itu sendiri. Belajar yang efisien dapat tercapai apabila dapat menggunakan strategi belajar yang tepat. Kesempatan ini model pembelajaran yang tepat digunakan ialah model pembelajaran inkuiri berbasis konsep jual beli pada matapelajaran statistika. Alasannya menggunakan materi statistika karena berdasarkan wawancara dengan salah satu guru matematika bahwa materi statistika tidak pernah mengunakan konsep jual beli dalam proses pembelajarannya sehingga diharapkan model yang akan dibuat ini adalah salah satu hal yang baru bagi siswa, guru, sekolah.

Mengingat permasalahan yang sedang terjadi, dan berdasarkan barunya model pembelajaran yang akan dirancang maka penulis ingin memberikan sumbangan pemikiran dalam hal kegiatan penelitian, dengan memilih judul penelitian: "Penerapan Model Pembelajaran Inkuiri Berbasis Konsep Jual Beli Terhadap Respon Siswa Pada Mata Pelajaran Statistika". Bertujuan untuk melihat bagaimana respon siswa pada mata pelajaran statistik melalui penerapan model pembelajaran inkuiri berbasis konsep jual beli pada mata pelajaran statistika.

\section{METODE}

Jenis penelitian adalah penelitian tindakan kelas (PTK). Adapun populasi penelitian ini adalah seluruh siswa SD IT FAZA AZKIA Kelurahan Hutaraja Kecamatan Muara Batang Toru sedangkan sampel dalam penelitian ini adalah siswa kelas V. Desain penelitian yang digunakan dalam penelitian ini adalah memiliki 4 tahap pada setiap siklusnya seperti berikut. 


\section{Perencanaan}

\section{Tindakan}

Observasi

Refleksi

Gambar 1. Prosedur Penelitian Tindakan Kelas

Instrumen yang digunakan untuk memperoleh data dalam penelitian ini adalah angket respon siswa. Analisis data dalam penilitian ini menggunakan tekhnik analisis kualitatif. Respon siswa dikatakan positif jika 80\% atau lebih, siswa merespon dalam kategori positif (senang, baru, berminat, jelas, dan tertarik) untuk setiap aspek yang direspon (Siregar, 2011). Rumus ini juga disajikan dengan bantuan Microsoft Excel.

Persentase respon siswa $=\frac{\text { jumlah respin siswa tiap aspek yang muncul }}{\text { jumlah seluruh siswa }} \times 100 \%$

\section{HASIL DAN PEMBAHASAN}

\section{Analisis Penelitian Tindakan Kelas Siklus I}

\section{Perencanaan}

Perencanaan yang dilakukan dalam penelitian tindakan kelas siklus I meliputi:

a) Analisis siswa untuk melihat kemampuan siswa untuk membedakan kemampuan tinggi, sedang dan rendah gunanya dalam penyusunan kelompok.

b) Analisis guru untuk melihat metode, media, strategi dan model pembelajaran yang dilakukan gunanya untuk mempersiapkan perangkat RPP yang menggunakan model pembelajaran inkuiri berbasis konsep jual beli dalam bentuk koperatif.

c) Analisis sekolah untuk melihat kondisi dan situasi sekitar sekolah gunanya untuk pembuatan toko mini dalam pelaksanaan konsep jual beli.

d) Analisis silabus, SK, KD, Materi gunanya untuk pembuatan LAS, dan tes.

e) Menyusun Silabus, RPP, LAS, Tes

f) Menyusun lembar angket respo siswa.

g) Menunjuk tim validator.

h) Melakukan validasi perangkat kepada tim validator untuk menilai, kritik, saran dan revisi yang harus dilakukan untuk menghasilkan perangkat yang lebih baik.

\section{Hasil Pelaksanaan dan pengamatan Penelitian Tindakan Kelas Siklus I}

Data yang diperoleh dianalisis, kemudian hasilnya digunakan sebagi alat untuk menjawab rumusan masalah. Data yang diperoleh berupa data angket respon siswa. Dari angket respon siswa yang diberikan kepada 30 siswa setelah mengikuti pembelajaran dengan menggunakan model pembelajaran inkuiri berbasis konsep jual beli untuk topik bahasan statistika, maka diperoleh hasil dengan rincian seperti tabel berikut ini.

Tabel 1. Hasil Angket Respon Siswa pada Siklus I

\begin{tabular}{|c|c|c|c|c|c|}
\hline \multirow[b]{2}{*}{ No } & \multirow[b]{2}{*}{ Aspek yang Diamati } & \multicolumn{2}{|c|}{ Respon Siswa } & \multicolumn{2}{|c|}{ Persentase } \\
\hline & & Senang & $\begin{array}{l}\text { Tidak } \\
\text { Senang }\end{array}$ & Senang & $\begin{array}{c}\text { Tidak } \\
\text { Senang }\end{array}$ \\
\hline \multirow[t]{7}{*}{1} & $\begin{array}{l}\text { Bagaimana perasaanmu terhadap } \\
\text { komponen }\end{array}$ & & & & \\
\hline & Materi Pelajaran & 23 & 7 & 76,667 & 23,333 \\
\hline & Lembar Aktivitas Siswa (LAS) & 27 & 3 & 90 & 10 \\
\hline & Suasana Belajar di Kelas & 30 & 0 & 100 & 0 \\
\hline & Cara Guru Mengajar & 28 & 2 & 93,333 & 6,667 \\
\hline & Konsep Jual Beli & 30 & 0 & 100 & 0 \\
\hline & & Baru & $\begin{array}{l}\text { Tidak } \\
\text { Baru }\end{array}$ & Baru & Tidak Baru \\
\hline \multirow[t]{2}{*}{2} & $\begin{array}{l}\text { Bagaimana perasaanmu terhadap } \\
\text { komponen? }\end{array}$ & & & & \\
\hline & Materi Pelajaran & 27 & 3 & 90 & 10 \\
\hline
\end{tabular}




\begin{tabular}{llrrrr}
\hline Lembar Aktivitas Siswa (LAS) & 29 & 1 & 96,667 & 3,333 \\
\hline Suasana Belajar di Kelas & 30 & 0 & 100 & 0 \\
\hline Cara Guru Mengajar & 29 & 1 & 96,667 & 3,333 \\
\hline Konsep Jual Beli & 30 & 0 & 100 & 0 \\
\hline 3 & Berminat & $\begin{array}{c}\text { Tidak } \\
\text { Berminat }\end{array}$ & Berminat & $\begin{array}{r}\text { Tidak } \\
\text { Berminat }\end{array}$ \\
\hline $\begin{array}{l}\text { Apakah kamu berminat } \\
\text { mengikuti kegiatan belajar } \\
\text { selanjutnya seperti yang telah } \\
\text { kamu ikuti sekarang ini? }\end{array}$ & 30 & 0 & 100 & 0 \\
\hline 4 & & & & Tidak \\
\hline $\begin{array}{l}\text { Bagaimana pendapatmu tentang } \\
\text { buku siswa dan Lembar Aktivitas }\end{array}$ & Ya & Tidak & Ya & \\
Siswa (LAS)? & & & & 6,667 \\
\hline $\begin{array}{l}\text { Apakah kamu dapat memahami } \\
\text { bahasa yang digunakan dalam } \\
\text { buku siswa/LAS? }\end{array}$ & 28 & 2 & 93,333 & 10 \\
\hline $\begin{array}{l}\text { Apakah kamu tertarik pada } \\
\text { penampilan (tulisan, ilustrasi, } \\
\text { gambar, dan letak gambarnya) } \\
\text { yang terdapat pada buku } \\
\text { siswa/LAS? }\end{array}$ & 27 & 3 & 90 & \\
\hline
\end{tabular}

Dari dapat dianalisis bahwa respon siswa masih ada ditemukan belum mencapai nilai minimal $80 \%$ yaitu masih berada di bawah nilai minimal yaitu 76,667\% sedangkan aspek yang lainnya sudah mencapai bahkan melebihi nilai minimal. Artinya masih ada aspek yang direspon belum positif oleh siswa sehingga perangkat pembelajaran perlu di perbaiki dan mengalami revisi berdasarkan respon siswa untuk pertemuan siklus berikutnya.

\section{Hasil Refleksi Siklus I}

Hasil analisis bahwa respon siswa masih ada ditemukan belum mencapai nilai minimal $80 \%$ yaitu pada aspek "Bagaimana perasaanmu terhadap komponen: (a) Materi Pelajaran pada indikator "Senang" masih berada di bawah nilai minimal yaitu 76,667\% sedangkan aspek yang lainnya sudah mencapai bahkan melebihi nilai minimal. Artinya masih ada aspek yang direspon belum positif oleh siswa hal ini diperkirakan karena materi masih baru bagi siswa dan model pembelajaran yang digunakan juga masih baru, sehingga perangkat pembelajaran perlu di perbaiki dan mengalami revisi berdasarkan respon siswa untuk pertemuan siklus berikutnya.

\section{Analisis Penelitian Tindakan Kelas Siklus II}

\section{Perencanaan}

Perencanaan yang dilakukan dalam penelitian tindakan kelas siklus II meliputi:

a. Analisis siswa untuk melihat kemampuan siswa untuk membedakan kemampuan tinggi, sedang dan rendah gunanya dalam penyusunan kelompok.

b. Analisis guru untuk melihat metode, media, strategi dan model pembelajaran yang dilakukan gunanya untuk mempersiapkan perangkat RPP yang menggunakan model pembelajaran inkuiri berbasis konsep jual beli dalam bentuk koperatif.

c. Analisis sekolah untuk melihat kondisi dan situasi sekitar sekolah gunanya untuk pembuatan toko mini dalam pelaksanaan konsep jual beli.

d. Analisis silabus, SK, KD, Materi gunanya untuk pembuatan LAS, dan tes.

e. Menyusun Silabus, RPP, LAS, Te kemampuan pemahaman konsep matematik.

f. Menyusun lembar angket respo siswa.

g. Menunjuk tim validator.

h. Melakukan validasi perangkat kepada tim validator untuk menilai, kritik, saran dan revisi yang harus dilakukan untuk menghasilkan perangkat yang lebih baik. 


\section{Hasil Pelaksanaan dan pengamatan Penelitian Tindakan Kelas Siklus II}

Data yang diperoleh dianalisis, kemudian hasilnya digunakan sebagi alat untuk menjawab rumusan masalah. Data yang diperoleh berupa data angket respon siswa. Dari angket respon siswa yang diberikan kepada 30 siswa setelah mengikuti pembelajaran siklus II dengan menggunakan model pembelajaran inkuiri berbasis konsep jual beli untuk topik bahasan statistika, maka diperoleh hasil dengan rincian seperti tabel berikut ini.

Tabel 2. Hasil Angket Respon Siswa pada Siklus II

\begin{tabular}{|c|c|c|c|c|c|}
\hline \multirow[t]{2}{*}{ No } & \multirow[t]{2}{*}{ Aspek yang Diamati } & \multicolumn{2}{|c|}{ Respon Siswa } & \multicolumn{2}{|c|}{ Persentase } \\
\hline & & Senang & $\begin{array}{c}\text { Tidak } \\
\text { Senang }\end{array}$ & Senang & $\begin{array}{c}\text { Tidak } \\
\text { Senang }\end{array}$ \\
\hline \multirow[t]{7}{*}{1} & $\begin{array}{l}\text { Bagaimana perasaanmu terhadap } \\
\text { komponen }\end{array}$ & & & & \\
\hline & Materi Pelajaran & 28 & 2 & 93,333 & 6,667 \\
\hline & Lembar Aktivitas Siswa (LAS) & 28 & 2 & 93,333 & 6,667 \\
\hline & Suasana Belajar di Kelas & 30 & 0 & 100 & 0 \\
\hline & Cara Guru Mengajar & 28 & 2 & 93,333 & 6,667 \\
\hline & Konsep Jual Beli & 30 & 0 & 100 & 0 \\
\hline & & Baru & $\begin{array}{l}\text { Tidak } \\
\text { Baru }\end{array}$ & Baru & Tidak Baru \\
\hline \multirow[t]{7}{*}{2} & $\begin{array}{l}\text { Bagaimana perasaanmu terhadap } \\
\text { komponen? }\end{array}$ & & & & \\
\hline & Materi Pelajaran & 29 & 2 & 96,667 & 6,667 \\
\hline & Lembar Aktivitas Siswa (LAS) & 29 & 1 & 96,667 & 3,333 \\
\hline & Suasana Belajar di Kelas & 30 & 0 & 100 & 0 \\
\hline & Cara Guru Mengajar & 30 & 0 & 100 & 0 \\
\hline & Konsep Jual Beli & 30 & 0 & 100 & 0 \\
\hline & & Berminat & $\begin{array}{c}\text { Tidak } \\
\text { Berminat }\end{array}$ & Berminat & $\begin{array}{c}\text { Tidak } \\
\text { Berminat }\end{array}$ \\
\hline \multirow[t]{2}{*}{3} & $\begin{array}{l}\text { Apakah kamu berminat mengikuti } \\
\text { kegiatan belajar selanjutnya seperti } \\
\text { yang telah kamu ikuti sekarang ini? }\end{array}$ & 30 & 0 & 100 & 0 \\
\hline & & Ya & Tidak & $\mathrm{Ya}$ & Tidak \\
\hline \multirow[t]{3}{*}{4} & $\begin{array}{l}\text { Bagaimana pendapatmu tentang } \\
\text { buku siswa dan Lembar Aktivitas } \\
\text { Siswa (LAS)? }\end{array}$ & & & & \\
\hline & $\begin{array}{l}\text { Apakah kamu dapat memahami } \\
\text { bahasa yang digunakan dalam buku } \\
\text { siswa/LAS? }\end{array}$ & 29 & 1 & 96,667 & 3,333 \\
\hline & $\begin{array}{l}\text { Apakah kamu tertarik pada } \\
\text { penampilan (tulisan, ilustrasi, } \\
\text { gambar, dan letak gambarnya) yang } \\
\text { terdapat pada buku siswa/LAS? }\end{array}$ & 29 & 1 & 96,667 & 3,333 \\
\hline
\end{tabular}

Dari tabel di atas dapat dianalisis bahwa respon siswa sudah mencapai nilai minimal $80 \%$ yaitu pada semua aspek. Artinya aspek yang direspon sudah positif oleh siswa sehingga perangkat pembelajaran tidak perlu diperbaiki dan mengalami revisi berdasarkan respon siswa sehingga tidak perlu lagi dilakukan pertemuan pada siklus berikutnya dengan materi yang sama.

\section{Hasil Refleksi Siklus II}

Hasil analisis bahwa respon siswa sudah mencapai nilai minimal $80 \%$ yaitu pada semua aspek hal ini diperkirakan karena siswa sudah merasa senang mengikuti pembelajaran dengan kelompok dan senang menggunakan konsep jual beli pada materi yang sedang dipelajari. Artinya aspek yang direspon sudah positif oleh siswa sehingga 
perangkat pembelajaran tidak perlu diperbaiki dan mengalami revisi berdasarkan respon siswa sehingga tidak perlu lagi dilakukan pertemuan pada siklus berikutnya dengan materi yang sama.

\section{Pembahasan}

Berdasarkan hasil-hasil yang diperoleh dalam pengujian hipotesis dapat dikemukakan bahwa penggunaan model pembelajaran dengan konsep jual beli guru harus mampu mengatur siswa dan sarana prasarana pembelajaran serta mengendalikannya dalam suasana yang menyenangkan untuk mencapai tujuan pembelajaran yang telah ditentukan. Hal ini sangat jelas sekali betapa pentingnya kemampuan dalam mengelola pembelajaran dimiliki oleh seorang pendidik. Pengelolaan kelas yang efektif merupakan prasyarat mutlak bagi tercapainya proses belajar mengajar yang efektif dan menyenangkan terutama bagi respon siswa.

Dari angket respon siswa yang diberikan kepada 30 orang siswa pada siklus I dapat dianalisis bahwa respon siswa masih ada ditemukan belum mencapai nilai minimal $80 \%$ yaitu pada aspek "Bagaimana perasaanmu terhadap komponen: (a) Materi Pelajaran pada indikator "Senang" masih berada di bawah nilai minimal yaitu 76,667\% sedangkan aspek yang lainnya sudah mencapai bahkan melebihi nilai minimal. Sedangkan angket respon siswa yang diberikan kepada 30 orang siswa pada siklus II dapat dianalisis bahwa respon siswa sudah mencapai nilai minimal $80 \%$ yaitu pada semua aspek. Artinya aspek yang direspon sudah positif oleh siswa sehingga perangkat pembelajaran tidak perlu diperbaiki dan mengalami revisi berdasarkan respon siswa sehingga tidak perlu lagi dilakukan pertemuan pada siklus.

\section{KESIMPULAN DAN SARAN \\ Kesimpulan}

Dari penelitian yang telah dilakukan dan berdasarkan analisis yang dilakukan tentang upaya yang di gunakan untuk meningkatkan respon positif siswa adalah dengan penggunaan model pembelajaran inkuiri berbasis konsep jual beli. Maka diperoleh kesimpulan: Angket respon siswa yang diberikan kepada 30 orang siswa pada siklus I masih ada ditemukan belum mencapai nilai minimal $80 \%$ atau masih berada di bawah nilai minimal yaitu 76,667\%. Sedangkan angket respon siswa yang diberikan kepada 30 orang siswa pada siklus II seluruh respon siswa sudah mencapai nilai minimal $80 \%$ yaitu pada semua aspek. Sehingga respon siswa terhadap pembelajaran sudah positif dan ini terjadi peningkatan dari siklus I sampai siklus II.

\section{Saran}

Berdasarkan hasil penelitian ini, model pembelajaran inkuiri berbasis konsep jual beli pada kegiatan pembelajaran dengan koperatif memberikan beberapa hal yang penting untuk diperhatikan. Untuk itu peneliti menyarankan beberapa hal: (1) Bagi guru yang ingin mengajarkan materi statistika sudah efektif dan mampu menciptakan respon yang positif menggunakan model pembelajaran koperatif dengan berbasis konsep jual beli. (2) Bagi guru-guru yang ingin mengajar di tingkat SD untuk menerapkan model inkuiri berbasis konsep jual beli karena siswa sangat merasa senang mengikuti model pembelajaran inkuiri, selain itu juga rasa tanggung jawab pada anak semakin terlatih akibat koperatif yang dibentuk. (3) Perlu dilakukan penelitian terkait model pembelajaran inkuiri dengan konsep jual beli untuk meningkatkan kemampuan-kemampuan matematik yang lain dan untuk materi yang lain.

\section{DAFTAR PUSTAKA}

Djamarah, S. B., Zain, A. 2006. Strategi Belajar Mengajar Edisi Revisi. Jakarta: PT Rineka Cipta. 
Herawati, O. D. P, dkk. 2010. Pengaruh Pembelajaran Problem Posing Terhadap Kemampuan Pemahaman Konsep Matematika Siswa Kelas XI IPA SMA Negeri 6 Palembang. Jurnal Pendidikan Matematika, 4(1).

Kunandar. 2009. Guru Profesional Implementasi kurikulum Tingkat Satuan Pendidikan (KTSP) dan Sukses dalam Sertifikasi Guru. Jakarta: Rajawali Pers.

Rohman, M., Amri, S. 2013. Strategi \& Desain Pengembangan Sistem Pembelajaran. Jakarta: Prestasi Pustaka.

Siregar, S. U. 2011. Pengembangan Perangkat Pembelajaran Berbasis Masalah dalam Peningkatan Kemampuan Pemecahan Masalah Siswa Kelas V MIN pada Pokok Bahasan Pecahan. Medan: Program Pascasarjana Unimed Medan. 